\title{
Holocene Volcanism of Northern Kamchatka: The Spatiotemporal Aspect
}

\author{
M. M. Pevzner \\ Presented by Academician Yu. M. Pushcharovsky November 29, 2005
}

Received December 12, 2005

DOI: $10.1134 / \mathrm{S} 1028334 \mathrm{X} 06060109$

It is common practice to relate young (including Holocene) volcanism in the Kamchatka Peninsula to the Pacific Plate subduction. According to seismic sounding data, its northern boundary is drawn along the latitudinal fragment of the Kamchatka River, and Shiveluch Volcano is regarded as the northernmost active volcano [1, 4, 11, 12, and others] (figure, inset). In accordance with this postulate, the presence of Holocene volcanic centers in the peninsula regions located further north was refuted, and no prospecting for them has been carried out until recently. In the present paper, the notion of "northern Kamchatka" (NK) includes regions north of Shiveluch Volcano and the western Alnei-Chashakondzha volcanic massif.

Based on results of the detailed deciphering of aerial photos and space images, the northern Sredinnyi Ridge and the Elovka River basin incorporate a series of monogenic volcanic structures (slag cones, lava flows, and explosion craters), as well as several well-preserved stratovolcanoes, which lack traces of glacier raft. Since 2002, we carried out complex tephrochronological, petrological-geochemical, and radiocarbon investigations on the checking and dating of presumably Holocene objects.

We studied more than 200 sections of the Holocene soil-pyroclastic cover (SPC) developed as both "local" volcanogenic rocks and key horizons of transit ash of distant volcanoes. The horizons were used as geochronological reference [10] for correlating rare sections and compiling composite Holocene sections. Rocks of NK volcanic centers in the SPC are mainly represented by tephra: inequigranular volcanic sand with gravel and lapilli (black slags are typical for monogenic centers; white, pale, yellow, pinkish, and light gray pumice and mineral sands, for stratovolcanoes). Affinity of the SPC ash to NK volcanic centers is proved by a regular

Geological Institute, Russian Academy of Sciences, Pyzhevskii per. 7, Moscow, 119017 Russia;

e-mail: suler@ginras.ru increase in the number of interlayers, their thickness, and grain size of the material near separate eruptive centers. Moreover, the ash composition was compared to massive rocks (lava and pyroclastic flows) of probable eruption sources, and a special paper will be devoted to this issue.

The timing of stratovolcano eruptions was established by the ratio between horizons of "new" ash and key interlayers of transit ash, as well as by radiocarbon dating of the organic material from rocks underlying and (or) overlying the volcanic rocks. The age of monogenic volcanic centers was determined by the position of associated pyroclastic material in the composite tephrastratigraphic section and by the analysis of the time interval of the beginning of SPC deposition on young lava flows. The present paper is based on more than $150{ }^{14} \mathrm{C}$ analyses at the Geological Institute, Moscow.

In the Sredinnyi Ridge in Kamchatka, we can outline three stratovolcanoes that were active in the Holocene (figure).

Alnei Volcano $\left(56^{\circ} 41^{\prime} \mathrm{N}, 159^{\circ} 38^{\prime} \mathrm{E}, 2598.0 \mathrm{~m}\right)$, the main summit of the Alnei-Chashakondzha Massif, is situated on the watershed of the Kirevna, Belaya, and Kalgaucha rivers $100 \mathrm{~km}$ west of Shiveluch Volcano. The volcano was active through the whole Holocene: more than 30 pyroclastic horizons have been established in this area. The last intense eruption took place about 350 yr ago (hereinafter, ${ }^{14} \mathrm{C}$ age is given).

Gornyi Institut Volcano $\left(57^{\circ} 20^{\prime} \mathrm{N}, 160^{\circ} 11^{\prime} \mathrm{E}\right.$, $2125.2 \mathrm{~m}$ ) is situated on the watershed of the Kunkhilok, Sedanka, and Vtoraya Rassoshina rivers $100 \mathrm{~km}$ northwest of Shiveluch Volcano. Here we have identified more than 20 pyroclastic horizons associated with volcanic eruptions, including a pyroclastic flow on the southern slope of a volcano formed $\sim 950 \mathrm{yr}$ ago. The last intense eruption occurred $700 \mathrm{yr}$ ago.

Spokoinyi Volcano $\left(58^{\circ} 08^{\prime} \mathrm{N}, 160^{\circ} 49^{\prime}\right.$ E, $\left.2170.6 \mathrm{~m}\right)$ is situated on the watershed of the Levaya Nachika and Kutina rivers $170 \mathrm{~km}$ north-northwest of the Shiveluch Volcano. The volcano was active only in the early and 


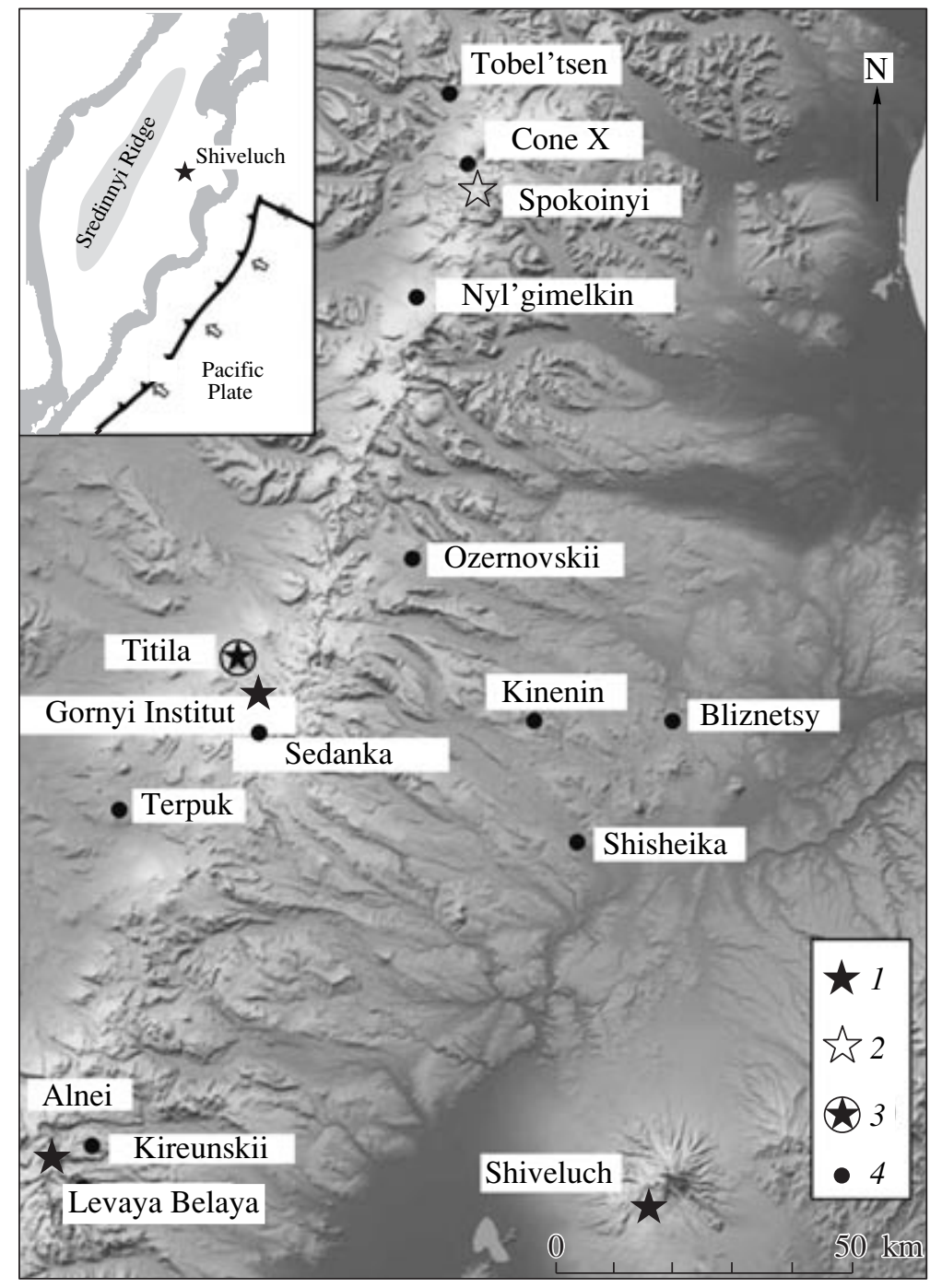

Holocene volcanic centers of northern Kamchatka. (1, 2) Stratovolanoes: (1) active, (2) extinct; (3) active shield volcano; (4) monogenic volcanic edifices.

middle Holocene. This is marked by five eruptions, including the last event $\sim 5.4 \mathrm{ka}$ ago.

The eruption history of the mentioned stratovolcanoes includes subsynchronous periods (early and late Holocene; the early Holocene only for Spokoinyi Volcano) similar to those characteristic of the Khangar [2] and Ichinskii [9] volcanoes located in the southern part of the Sredinnyi Ridge. According to the existing concepts, a volcano with at least one eruption recorded over the past $3.0-3.5 \mathrm{ka}$ is considered an active structure [6]. Hence, the Alnei and Gornyi Institut volcanoes should be assigned to potentially hazardous structures in Kamchatka. It is likely that the Spokoinyi Volcano is already extinct, and it will hardly be active in the future.

According to data of my colleagues, the Titila Volcano $\left(57^{\circ} 24^{\prime} \mathrm{N}, 160^{\circ} 07^{\prime} \mathrm{E}, 1559.6 \mathrm{~m}\right)$ located in the axial part of the Sedanka Dol $10 \mathrm{~km}$ northwest of the Gornyi Institute Volcano summit should also be attrib- uted to active volcanoes. Its last eruption took place about $2.5 \mathrm{ka}$ ago [5].

Monogenic structures. In the SPC of the northern Sredinnyi Ridge, we have recognized and dated numerous black slag sand deposits, which mark episodes of the origin of monogenic volcanic centers. Unfortunately, young slag cones and lava flows are partly located in the near-axial part of the ridge with permanent snow and ice cover that prevents their study. In this work, we consider only monogenic centers for which the eruption source has been established (figure). Most of the Holocene monogenic centers of the Sredinnyi Ridge are confined to slopes and foothills of stratovolcanoes that were also active in the Holocene (see above).

The eastern foothill of the Alnei-Chashakondzha Massif incorporates the 2.6-ka-old successions of the Levaya Belaya River (source at $56^{\circ} 38^{\prime} \mathrm{N}, 159^{\circ} 43^{\prime} \mathrm{E}$, 
$1366.0 \mathrm{~m}$ ) and the Kireunskii $\left(56^{\circ} 41^{\prime} \mathrm{N}, 159^{\circ} 44^{\prime} \mathrm{E}\right.$, $1400.0 \mathrm{~m}$ ) lava flows [7, 8].

Several major slag cones with vast lava fields and the Terpuk volcanic massif $\left(57^{\circ} 19^{\prime} \mathrm{N}, 159^{\circ} 50^{\prime} \mathrm{E}, 765.2 \mathrm{~m}\right)$ formed on the Sedanka Dol (the western slope of the ridge near the Gornyi Institut Volcano) in the early (8.0$10.0 \mathrm{ka}$ ago) and late (2.5-3.0 ka ago) Holocene [5].

About $6.2 \mathrm{ka}$ ago, the Sedanka lava flow $\left(57^{\circ} 19^{\prime} \mathrm{N}\right.$, $160^{\circ} 12^{\prime} \mathrm{E}, 1600.0 \mathrm{~m}$ ) poured out on the southern slope of the Gornyi Institute Volcano at the Sedanka River source.

The early Holocene (9.0-10.0 ka ago) Ozernovskii flow $\left(57^{\circ} 35^{\prime} \mathrm{N}, 160.38^{\prime} \mathrm{E}, 964.5 \mathrm{~m}\right)$ is located on the eastern slope of the ridge at the source of the Pravaya and Levaya Ozernaya rivers [8].

The $N y l^{\prime}$ gimelkin lava flow and slag cones $\left(57^{\circ} 58^{\prime} \mathrm{N}\right.$, $160^{\circ} 39^{\prime} \mathrm{E}, 1621.0 \mathrm{~m}$ ) formed as a result of a fissure eruption on the northwestern slope of the old Khuvkhoitun Volcano $\sim 5.5 \mathrm{ka}$ ago. They are mentioned as the Atlasov Volcano in [3].

A nameless summit ("Cone X") $2127.5 \mathrm{~m}$ high is situated in the near-axial part of the ridge $4 \mathrm{~km}$ northwest of the Spokoinyi Volcano. The lava flow and a small slag cone crowning the edifice $\left(58^{\circ} 10^{\prime} \mathrm{N}, 160^{\circ} 48^{\prime} \mathrm{E}\right)$ formed about $4.0 \mathrm{ka}$ ago.

The northernmost area of the studied Holocene monogenic centers of the Sredinnyi Ridge and Kamchatka includes the Tobel'tsen cone $\left(58^{\circ} 15^{\prime} \mathrm{N}, 160^{\circ} 44^{\prime} \mathrm{E}\right.$, $831.8 \mathrm{~m}$ ) and an associated lava flow embedded into the Voyampolki River valley. The Tobel'tsen Massif formed $\sim 3.5 \mathrm{ka}$ ago. The cone is located $15 \mathrm{~km}$ northnorthwest of the Spokoinyi Volcano, and hence, $180 \mathrm{~km}$ of the Shiveluch Volcano.

The basin of the Elovka River, the largest left tributary of the Kamchatka River, can be regarded as the northern extension of the Central Kamchatka Depression. Three late Holocene monogenic centers have been studied in the upper course of the Elovka River and its tributaries. The Shisheika lava flow $\left(57^{\circ} 09^{\prime} \mathrm{N}, 161^{\circ} 05^{\prime} \mathrm{E}\right.$, $378.5 \mathrm{~m}$ ), which formed $4.2 \mathrm{ka}$ ago, is located on the right bank of the Shishei River, $10 \mathrm{~km}$ upstream of the river mouth, and hence, $60 \mathrm{~km}$ north-northwest of the Shiveluch Volcano.

The Bliznetsy lava flows $\left(57^{\circ} 21^{\prime} \mathrm{N}, 161^{\circ} 22^{\prime} \mathrm{E}\right.$, $265.0 \mathrm{~m}$ ), which poured out of adjacent centers about $3.0 \mathrm{ka}$ ago, are located on the interfluve of the Elovka and Ozernaya rivers, $80 \mathrm{~km}$ north of the Shiveluch Volcano [8].

The Kinenin Maar $\left(57^{\circ} 21^{\prime} \mathrm{N}, 160^{\circ} 58^{\prime}\right.$ E, $\left.583.4 \mathrm{~m}\right)$, which is located at the eastern foothills of the Sredinnyi Ridge on the creek of the same name (the upper right tributary of the Elovka River), $80 \mathrm{~km}$ north-northwest of the Shiveluch Volcano, formed about $11.0 \mathrm{ka}$ ago [8].

\section{CONCLUSIONS}

Numerous manifestations of the Holocene volcanism within northern Kamchatka have been established and dated for the first time. In particular, two new active and potentially hazardous stratovolcanoes (Alnei and Gornyi Institut) have been revealed in the Sredinnyi Ridge. Monogenic volcanic centers are confined to different volcanotectonic structures, such as the Sredinnyi Ridge (eruptions were established throughout the Holocene along the ridge profile) and the Elovka Depression (eruptions in adjacent areas only in the middle and late Holocene). The data obtained not only supplement, but also refine our concept on the spatiotemporal distribution of young volcanism in Kamchatka. The mechanism of magma generation other than subduction of the Pacific Plate can be assumed for volcanoes of northern Kamchatka, since most volcanic objects revealed in this region are located northward of the Aleutian transform fault.

\section{ACKNOWLEDGMENTS}

The author is grateful to L.D. Sulerzhitsky for great assistance and support in the work, as well as to A.D. Babanskii, A.O. Volynets, T.G. Churikova, V.V. Ponomareva, I.V. Melekestsev, L.I. Bazanova, O.V. Dirksen, and other colleagues who promoted the successful accomplishment of this work.

This work was supported by the Russian Foundation for Basic Research (project nos. 02-05-64991, 03-0565007, and 05-05-64776) the Presidium of the Russian Academy of Sciences (basic research program no. 13).

\section{REFERENCES}

1. G. P. Avdeiko, S.V. Popruzhenko, and A.A. Palueva, Geotectonics 36 (4), 312 (2002) [Geotektonika 36 (4), 64 (2002)].

2. L. I. Bazanova and M. M. Pevzner, Dokl. Earth Sci. 377A, 307 (2001) [Dokl. Akad. Nauk 377, 800 (2001)].

3. N. V. Ogorodov, N. N. Kozhemyaka, A. A. Vagisevskaya, and A. Ogorodova, Volcanoes and Quaternary Volcanism in the Sredinnyi Ridge of Kamchatka (Nauka, Moscow, 1972) [in Russian].

4. Active Volcanoes of Kamchatka, Ed. by S.A. Fedotova (Nauka, Moscow, 1991), Vol. 1 [in Russian].

5. O. V. Dirksen, L. I. Bazanova, and M. V. Portnyagin, Volcanism and Geodynamics. II All-Russia Symposium on Volcanology and Paleovolcanology (Ekaterinburg, 2003), pp. 871-874 [in Russian].

6. I. V. Melekestsev, O. A. Braitseva, and V. V. Ponomareva, in Geodynamics and Volcanism of the Kurile-Kamchatka Island-Arc System, (Petropavlovsk-Kamchatskii, 2001), pp. 191-203 [in Russian].

7. M. M. Pevzner, Volcanism and Geodynamics. II All-Russia Symposium on Volcanology and Paleovolcanology (Ekaterinburg, 2003), pp. 695-698 [in Russian]. 
8. M. M. Pevzner, Interrelation between Tectonics, Seismicity, Magma Formation, and Eruptions in Volcanic Arcs. IV International Conference on Kurile-Kamchatka-Aleutian Volcanic Arcs (Petropavlovsk-Kamchatskii, 2004), pp. 72-76 [in Russian].

9. M. M. Pevzner, Dokl. Earth Sci., 395, 437 (2004) Dokl. Akad. Nauk 395, 507 (2004)].

10. O. A. Braitseva, V. V. Ponomareva, L. D. Sulerzhitsky, and J. Bailey, Quatern. Res. 47, 125 (1997).
11. A. Gorbatov, V.V. Kostoglotov, G. Suarez, and E. Gordeev, J. Geophys. Res. 102, 17883 (1997).

12. V. Levin, J. Park, M. Brandon, et al., Tectonophysics 358, 233 (2002).

13. M. M. Pevzner, V. V. Ponomareva, and L. I. Bazanova, III Biennial Workshop on Subduction Processes Emphasizing the Kurile-Kamchatkan-Aleutian Arcs, Fairbanks, Alaska, 2002. 